疄学椎. (J. Japan. Soc. Hort. Sci.) 60(1) : 183-190. 1991.

\title{
青ウメの常温貯蔵におけるエチレン除去剤と ポリエチレン密封包装の影響
}

\author{
張 世明・茶珍和雄・岩田 隆 \\ 大阪府立大学脤学部 591 堺市百舌鳥梅町
}

\begin{abstract}
Effects of Polyethylene Packaging and Ethylene Absorbent on Storage of Mature-green Mume (Prunus mume Sieb. et Zucc.) Fruits at Ambient Temperature
\end{abstract}

Shiming Zhang, Kazuo Chachin and Takashi Iwata

College of Agriculture, University of Osaka Prefecture, Sakai, Osaka 591

\begin{abstract}
Summary
The effects of packaging with polyethylene bags and the inclusion of ethylene absorbent and/or $\mathrm{CO}_{2}$ absorbent on the keeping quality of mume (Japanese apricot) fruits were investigated. Concurrently, the concentrations of oxygen, carbon dioxide, ethylene, ethyl alcohol, and acetaldehyde in the bags and their production by the fruits were monitored.

1. Yellowing and softening of green mume fruit were noticeably retarded by the combination of packaging with polyethylene bags $(0.02 \mathrm{~mm})$ and the inclusion of an ethylene absorbent. This retardation of the ripening process was reversed when a carbon dioxide absorbent was included.

2. The inclusion of ethylene absorbent in the bags kept ethylene concentration at very low level, whereas oxygen concentration was higher and carbon dioxide concentration lower compared with bags in which the absorbents were omitted. In sealed bags with carbon dioxide absorbent or without both absorbents, acetaldehyde and ethyl alcohol accumulated, resulting in a physiological disorder known as internal browning. Addition of the ethylene absorbent suppressed the accumulation of both volatiles and prevented the occurrence of the internal browning. Inclusion of carbon dioxide absorbent with ethylene absorbent negated the beneficial effect of the latter and resulted in the accumulation of volatiles which induced the physiological disorder.

3. The respiration rate of the fruit was slower in sealed polyethylene bags with ethylene absorbent than in that without the absorbent; this suppression of respiration was overcome by the inclusion of the carbon dioxide absorbent. The ACC (1-aminocyclopropane-1-carboxylic acid) content in the fruit changed, parallelling the trends of ethylene evolution in all treatments. Among the different treatments, the ethylene forming enzyme (EFE) activity was lowest in fruits sealed in polyethylene bags containing the ethylene absorbent.
\end{abstract}

\author{
緒言

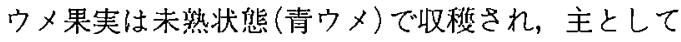 \\ 梅酒や性干しなどに加工されて用いられる。青ウメは

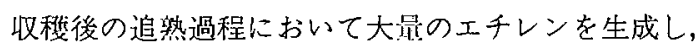 \\ 黄化や果肉の軟化が急速に進み，非常に商品性が低下 \\ しやすい $(2,7)$. プラスチックフィルム密封包装が青果
}

1990 年 5 月 15 日 受理。
物の鮮度保持に有効なことはよく知られているが(3)， 包装内の炭酸ガスや酸素波度の変化，または青果物の 異常代謝産物であるアセトアルデヒドやエチルアルコー ルの蓞程によって青果物に生理障害が発生するので問 題になることも多い $(10)$.

近年, 鮮度保持剂としてエチレン除去䠼が多く利用 されるようになったが $(5,9)$, エチレン除去剤とポリエ チレンフィルム创装の併用がカキ, ウメ, カボスなど 
の眝蔵にかなり效果のあることが報告されている $(7,8$, 10). 一方, ‘キャンベル・アーリー’ブドウ果実の研究 では気相中に出てきたエチレンを除去剂で取り除いて も，脱粒防止はできなかったと報告している(11)。ま た，この場合エチレンが気相中に存在しても，5－6\% の炭酸がスが存在すれば脱粒を抑えたといわれる.工 チレン除去剤の使用効果は青果物の種類が変わればも ちろん，同一種類の青果物でも一定ではなく，包装内 の酸素および炭酸がスレベルと関連して考感しなけれ ばならないと思われる。

本実験では青ウメ果実の包装眝藏における包装内力゙ 又組成・泿度の変化あるいはエチレン除去や炭酸がス の除去が果実の品質, 呼吸最, エチレン生成量, $\mathrm{ACC}$ 含星, エチレン生成醉素活性(EFE)，アセトアルデヒ ドおよびエチルアルコール生成に及ばす影響について 調べた。

\section{材料および方法}

供試材料には和歌山目果樹園芸試眕場紀北分場で栽 培された青ウメ“古城”を 1987 年 6 月 12 日に同一樹か

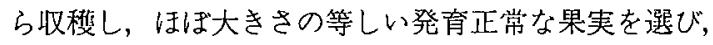
果実 $500 \mathrm{~g}$ (約 25 個)ずつを収穫当日に低密度ポリエチ レン袋 $(0.02 \times 260 \times 380 \mathrm{~mm})$ に入れ，有孔区(袋の両 面に直径 $5 \mathrm{~mm}$ の穴を 16 個あけたもの), 密封区, エ チレン除去剤封入区(過マンガン酸カリウム系のエチレ ン除去郕 $10 \mathrm{~g}$ を封入したもの)，炭酸がス吸収郕封入区 (ソーダライム $30 \mathrm{~g}$ を封入したもの), 炭酸がス吸収剤+ エチレン除去㓮封入区(ソーダライムとエチレン除去剤 を封入したもの)を設けた。

貯藏温度は常温 $\left(23^{\circ} \pm 2{ }^{\circ} \mathrm{C}\right)$ とした，果奏の表面色は 日本電色工業(侀製の測色色差計で測定し，各処理区 8 個ずつ 3 反復の測定值の平均值で表示した，果肉硬度 は荆皮後赤道部についてカードメーター(飯尾電機製, 直径 0.6 または $3 \mathrm{~mm}$ プランジャー) で測定した。

果実の生理障害発生の状態は果実を切断し，果実内 部の褐変や軟化状態を調べた。

ポリエチレン袋内のガス湍度は注射器で袋内ガスを 一定量採取してガスクロマトグラフィーで測定した。 果実からの炭酸ガス，エチレン，アセトアルデヒド， エチルアルコール発生量は果実を袋から取り出し， 1 時間空気中に放置後, 呼吸測定用がラス容器に密封し, 一定時間後にそのへッドスペースガスの一定显を注射 器で採取し，ガスクロマトグラフィーで測定した。

エチレンの測定は活性アルミナカラム $(60$ ～ 80 mesh, $\left.2 \mathrm{~m} \times 3 \mathrm{~mm} \phi, 70^{\circ} \mathrm{C}\right), \mathrm{FID}$ 検出器, 炭酸がスの測定
はPolapakQ カラム $60^{\circ} \mathrm{C}$ ), TCD 検出器, 酸奖の測定は Molecular Sieve $5 \mathrm{~A}$ 力ラム $\left(40 \sim 60\right.$ mesh, $\left.2 \mathrm{~m} \times 3 \mathrm{~mm} \phi, 60^{\circ} \mathrm{C}\right)$, $\mathrm{TCD}$ 検出器を用いた。 アセトアルデヒドとエチルアル コールの測定は $25 \%$ PEG 6000 カラム (30 60 mesh, 2 $\left.\mathrm{m} \times 3 \mathrm{~mm} \phi, 70^{\circ} \mathrm{C}\right)$ で行い, 検出器は FID を用いた. キャリアーガスとしてはいずれもへリウムを用いた。

果実の ACC (1-アミ)シクロプロパンー1ーカルボン 酸)含量はLizada・Yangの方法(6)で，エチレン生成 酵素活性は組織切片のエチレン生成に対する ACC 添加 (終末湠度 $2 \mathrm{mM}$ ) 効果によって測定した。

\section{実験結果}

\section{1. 果実表面色の変化}

ウメ果実の緑色は有孔区では販蒇 2 日までよく保持 されたが，貯藏 4 日に黄緑色となり，貯藏 6 日では完 全に黄化した，他の处理区では貯藏4日まで果実の緑 色は同椂に保持されたが，眝藏 6 日になると，エチレ ン除去剂封入区 $(\mathrm{E}-\mathrm{ab})$ を除いて残りの 3 区も緑色の褪 色が認められ，黄化指数 $\mathrm{L} \times \frac{\mathrm{b}}{|\mathrm{a}|}$ も高くなった(第 1 表)。エチレン除去剤封入区は貯藏 8 日まで果実の緑色 が保持された。

\section{2. 果実内部の生理障害発生と果肉硬度の变 化}

眝藏中の果実は有孔区とエチレン除去剤封入区にお いては果皮および果箺内部の状態は正常であった。密 封区と炭酸がス吸収刘封入区では, 詝藏 4 日後果実表 面には異常がみられなかったが，果箺内部，特に核の 周辺に水浸状の障害が発生しはじめ, 貯藏 5 日にはそ の障害発生率は $50 \%$ 以上に，6日には 100\%に達した。 岸酸ガス吸収剤十エチレン除去㓮封入区では盯藏 5 日 では障害発生率は 27\%であったが，6日に 100\%になっ た(第 2 表)。

果肉硬度は第 3 表のよjに, 貯藏 2 日から有孔区, 密封区，炭酸ガス吸収剤封入区では急激に低下したの に对してエチレン除去戍封入区では販藏 6 日まで高い 值で保持された，炭酸がス吸収剤十エチレン除去剤封 入区では眝藏 4 日まで軟化が比較的抑之られたが，果 実内部の障害発生が多くなった 6 日の封点で急激に敕 化した。

\section{3.包装内ガス組成と濃度の変化}

各処理区に损ける包装内の炭酸がス澱度の変化は第 1 図aのように, 密封区とエチレン除去剂封入区では 貯藏 1 日で炭酸がス洫度が約 $4 \%$ となり，その後，工 チレン除去㨈封入区では徐々に增加して6日後約 $6 \%$ 
Table 1. Effect of sealing in polyethyelene bags with or without an ethylene absorbent and/or a carbon dioxide absorbent on the surface color of 'Gojiro' mume fruits stored at $23^{\circ} \pm 2^{\circ} \mathrm{C}$.

\begin{tabular}{|c|c|c|c|c|c|c|c|c|c|c|c|c|}
\hline \multirow{3}{*}{ Treatments } & \multicolumn{12}{|c|}{ Days in storage } \\
\hline & \multicolumn{4}{|c|}{2} & \multicolumn{4}{|c|}{4} & \multicolumn{4}{|c|}{6} \\
\hline & L & a & b & $\mathrm{L} \times \frac{\mathrm{b}}{|\mathrm{a}|}$ & $\mathrm{L}$ & $\mathrm{a}$ & b & $\mathrm{L} \times \frac{\mathrm{b}}{|\mathrm{a}|}$ & L & a & b & $\mathrm{L} \times \frac{\mathrm{b}}{|\mathrm{a}|}$ \\
\hline Perf." & 47.2 & -11.5 & 20.6 & 84.6 & 55.9 & -6.2 & 28.3 & 255.2 & 57.7 & -0.6 & 31.2 & 3000.4 \\
\hline Seal ${ }^{y}$ & 43.3 & -11.6 & 20.7 & 84.4 & 47.2 & -11.5 & 20.9 & 85.8 & 52.3 & -5.7 & 26.4 & 242.2 \\
\hline$E-a b^{x}$ & 46.8 & -12.2 & 20.6 & 79.0 & 46.2 & -11.6 & 20.1 & 80.1 & 48.1 & -11.2 & 21.3 & 91.5 \\
\hline$C-a b^{w}$ & 47.1 & -11.2 & 21.0 & 88.9 & 48.1 & -11.1 & 22.0 & 95.3 & 51.7 & -9.6 & 24.9 & 134.1 \\
\hline$E \cdot C-a b^{v}$ & 47.2 & -11.7 & 20.5 & 82.7 & 46.9 & -12.2 & 20.7 & 79.6 & 52.2 & -5.9 & 25.7 & 227.4 \\
\hline
\end{tabular}

"Perforated polyethylene bag.

${ }^{y}$ Sealed in bag.

${ }^{x}$ Sealed with ethylene absorbent.

"Sealed with $\mathrm{CO}_{2}$ absorbent.

"Sealed with ethylene absorbent and $\mathrm{CO}_{2}$ absorbent.

Table 2. Effect of sealing in polyethylene bags with or without an ethylene absorbent and/or a carbon dioxide absorbent on the occurrence of physiological injury of 'Gojiro' mume fruits stored at $23^{\circ} \pm 2^{\circ} \mathrm{C}$.

\begin{tabular}{lcrrrr}
\hline & \multicolumn{5}{c}{ Days in storage } \\
Treatment" & 3 & & 4 & 5 & 6 \\
\hline Perf. & $0^{y}$ & & 0 & 0 & 0 \\
Seal & 0 & 9 & 57 & 100 \\
E-ab & 0 & 0 & 0 & 0 \\
C-ab & 0 & 16 & 64 & 100 \\
E:C-ab & 0 & 0 & 27 & 100 \\
\hline
\end{tabular}

" Treatments were same as in Table 1.

${ }^{y}$ Percent of injured (internal browning) fruits.

Table 3. Effect of sealing in polyethylene bags with or without an ethylene absorbent and/or a carbon dioxide absorbent on flesh firmness of 'Gojiro' mume fruits stored at $23^{\circ} \pm 2^{\circ} \mathrm{C}$.

\begin{tabular}{lccrr}
\hline Treatment" & \multicolumn{3}{c}{ Days in storage } & \\
\cline { 2 - 5 } & 0 & 2 & 4 & 6 \\
\hline Perf. & $379^{y}$ & 231 & 60 & 14 \\
Seal & & 115 & 50 & 15 \\
E-ab & & 355 & 361 & 234 \\
C-ab & 101 & 72 & 12 \\
E.C-ab & 249 & 237 & 13 \\
\hline
\end{tabular}

"Treatments were same as in Table 1.

s. $\left(\times 10^{5} \mathrm{dyne}^{\mathrm{c}} \mathrm{cm}^{2}\right)$. 


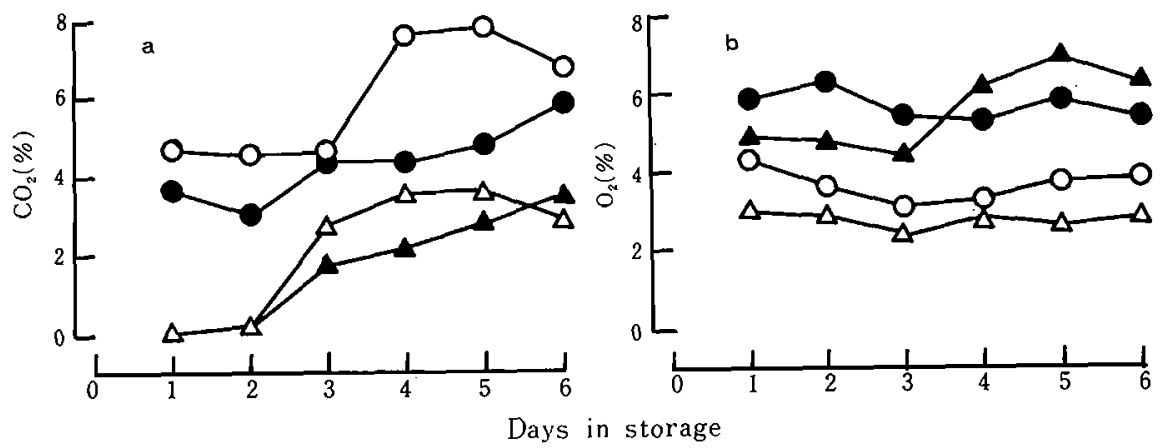

Fig. 1. Changes in $\mathrm{CO}_{2}$ (a) and $\mathrm{O}_{2}$ (b) concentrations in a polyethylene bag in which 'Gojiro' mume fruits were sealed with or without an ethylene absorbent and/or a carbon dioxide absorbent and stored at $23^{\circ} \pm 2^{\circ} \mathrm{C}$. O; sealed, $\bullet$; sealed with $\mathrm{C}_{2} \mathrm{H}_{4}$ absorbent, $\triangle$; sealed with $\mathrm{CO}_{2}$ absorbent, $\Delta$; sealed with $\mathrm{C}_{2} \mathrm{H}_{4}$ and $\mathrm{CO}_{2}$ absorbents.

になったのに対して，密封区では盯藏 4 日後急增し， 以後 6 ー 8\%を示した．炭酸がス吸収郕を封入した二 つの処理区では 2 日まで岸酸がス浱度の增加は抑之ら れたが，3日以降約 $3 \%$ 增加した。

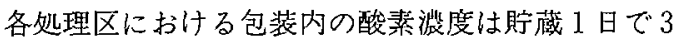
〜 6\%に急滅したが，エチレン除去猎を封入した二つ の処理区では封入していない処理区より約 $2 \sim 3 \%$ 高 い傾向がみられ，炭酸がス吸収剤封入区では最も低く 約 3\%を推移した(第 1 図b). 包装内のエチレン搌度 仕第2四のように，エチレン除去剤を封入した 2 処理 区ではほとんど蓄稓しなかったのに対して，密封区と 岸酸がス吸収剤封入区では貯藏 3 日以降急激に増加し, 800〜 $1000 \mathrm{ppm}$ の非常に高いレベルに達した。

嫌気的条件下における代謝産物であるアセ卜アルデ ヒドとエチルアルコールは，エチレン除去戍封入区に おいては包装内での増加が認められなかったが，密封 区と炭酸がス吸収剂封入区では眝藏 2 日から経時的に 増加した。炭酸がス吸収剤＋エチレン除去剤封入区で は眝藏 3 日まで增加が抑之られたが，4 日から急激に 増加し, 高い值を示した(第 3 図)。

4. 果実の炭酸ガス排出量, エチレン生成

量，アセトアルデヒドおよびェチルアル $コ ー ル$ 生成量の变化

第 1〜3図に示した袋内ガス組成・濃度の変化は主 に果実の呼吸作用の変化によっていると考えられるの で，包装ポリエチレン袋を開封し，1時間放置後にお ける果実炭酸がス排出量, エチレン生成是，アセトア ルデヒドおよびエチルアルコール生成量を測定し，そ の結果を第 4 〜 图に示した。果実の炭酸がス排出量

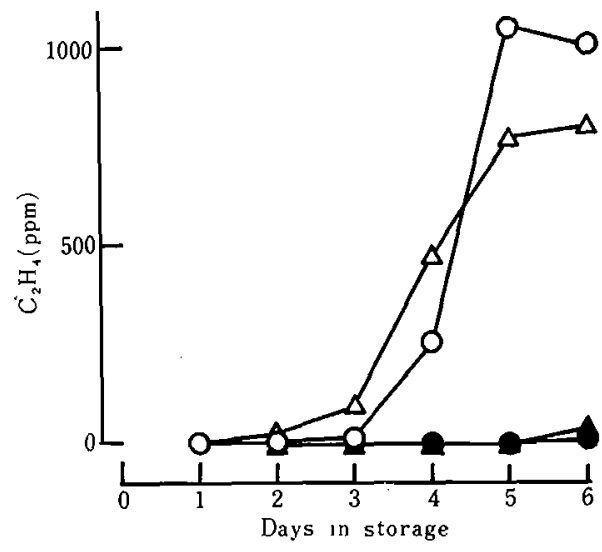

Fig. 2. Changes in $\mathrm{C}_{2} \mathrm{H}_{4}$ concentrations in a polyethylene bag in which 'Gojiro' mume fruits were sealed with or without an ethylene absorbent and/or a carbon dioxide absorbent and stored at $23^{\circ} \pm 2^{\circ} \mathrm{C}$. O; sealed, $\bullet$; sealed with $\mathrm{C}_{2} \mathrm{H}_{4}$ absorbent, $\triangle$; sealed with $\mathrm{CO}_{2}$ absorbent, $\Delta$; sealed with $\mathrm{C}_{2} \mathrm{H}_{4}$ and $\mathrm{CO}_{2}$ absorbents.

は，有孔区では貯藏 3 日に急激に増加して4 日にピ一 クを示し，その後減少して典型的な呼吸のクライマク テリック・ライズを示したのに対して，密封区では眝 藏4日にピークを示したが有孔区より低く，岸酸がス 吸収剂封入区では眝藏 2 日から増加し，3 日に緩やか なピークを示した。エチレン除去郕封入区と岸酸がス 吸収剤十エチレン除去剂封入区では貯藏後半に少し增 加するのみであった(第 4 図).

果実のエチレン生成量は，有孔区に扔いて盯蔵 3 日 には急激に增加し，4－5日に $1000 \mu \mathrm{l} / \mathrm{kg} / \mathrm{hr}$ 以上の 非常に高い值を示したのに対して，密封区では眝藏 2 


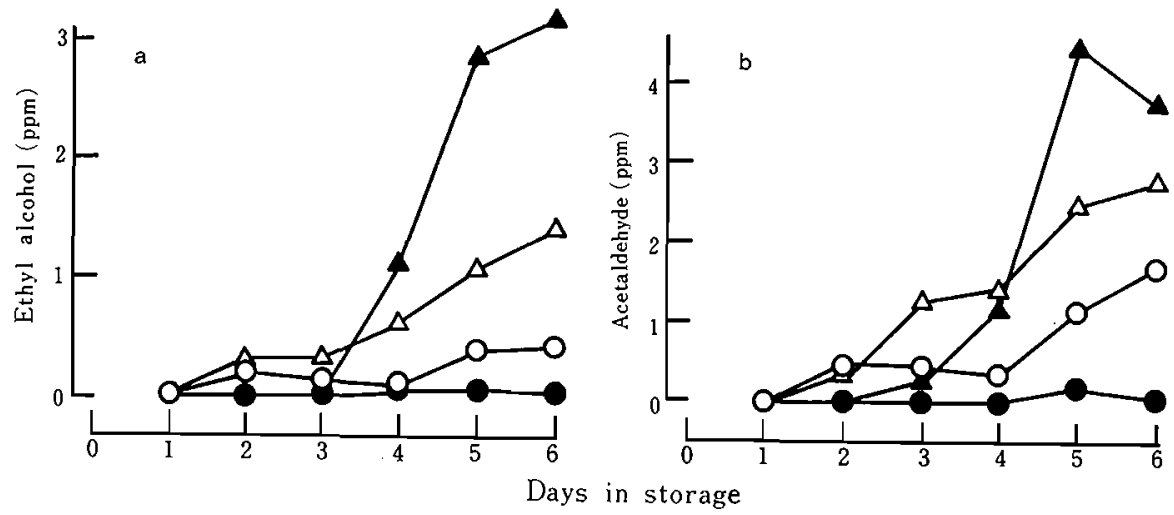

Fig. 3. Changes in ethyl alcohol (a) and acetaldehyde (b) concentrations in a polyethylene bag in which 'Gojiro' mume fruits were sealed with or without an ethylene absorbent and/or a carbon dioxide absorbent and stored at $23^{\circ} \pm 2^{\circ} \mathrm{C}$. O; sealed, $\bullet$; sealed with $\mathrm{C}_{2} \mathrm{H}_{4}$ absorbent, $\triangle$; sealed with $\mathrm{CO}_{2}$ absorbent, $\boldsymbol{\Delta}$; sealed with $\mathrm{C}_{2} \mathrm{H}_{4}$ and $\mathrm{CO}_{2}$ absorbents.

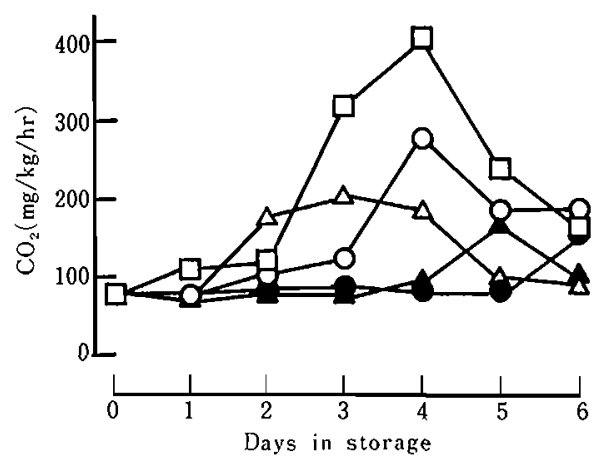

Fig. 4. Effect of sealing in polyethylene bags with or without an ethylene absorbent and/or a carbon dioxide absorbent on $\mathrm{CO}_{2}$ production of 'Gojiro' mume fruits during storage at $23^{\circ} \pm 2^{\circ} \mathrm{C}$. $\square$; perforated, $O$; sealed, $\bullet$ sealed with $\mathrm{C}_{2} \mathrm{H}_{4}$ absorbent, $\triangle$; sealed with $\mathrm{CO}_{2}$ absorbent, $\Delta$; sealed with $\mathrm{C}_{2} \mathrm{H}_{4}$ and $\mathrm{CO}_{2}$ absorbents.

日から4 日にかけて潮次增加し，その後急激に增加し て非常に高い值を示した，炭酸がス吸収唷封入区では 密湗区より早く增加した。エチレン除去剤を封入した 雨処理区では貯蔵 4 日まで増加が抑えられ，その後漸 次增加した(第 5 図)。

果実のエチルアルコール生成は，有孔区においては 貯藏4 日までほとんどなく，5 日に増加したが，非常 に少なかった．密封区では貯藏 2 日から增加し，4 日 にピークを示し，その後減少した，炭酸がス吸収刘封 入区では貯藏 2 日から 6 日にかけて徐々に增加した。 炭酸がス吸収剤＋エチレン除去剤封入区では貯蔵 4 日

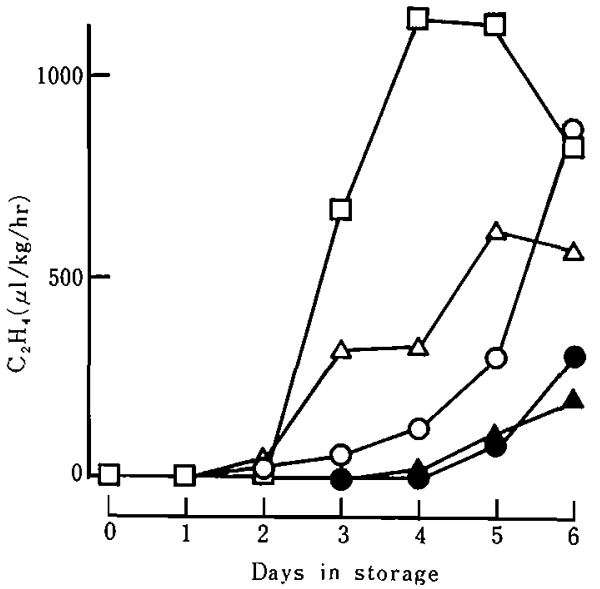

Fig. 5. Effect of sealing in polyetlyylene bags with or without an ethylene absorbent and/or a carbon dioxide absorbent on ethylene production of 'Gojiro' mume fruits during storage at $23^{\circ} \pm 2^{\circ} \mathrm{C}$. $\square$; perforated, $O$; sealed, - sealed with $\mathrm{C}_{2} \mathrm{H}_{4}$ absorbent, $\triangle$; sealed with $\mathrm{CO}_{2}$ absorbent, $\Delta$; sealed with $\mathrm{C}_{2} \mathrm{H}_{4}$ and $\mathrm{CO}_{2}$ absorbents.

まで增加しなかったが，5日から急激に增加し，非常 に高い值を示した。エチレン除去郕封入区では盯藏 5 日まで增加がみられなかったが，6日に少し増加した (第 6 図a)。果実のアセドアルデヒド生成昰の変化は エチルアルコール生成量の変化とほぼ同様の傾向を示 し，エチルアルコール生成是が高くなった洔期とアセ トアルデヒド生成量が高くなった時期とほぼ一致した (第 6 図b). 


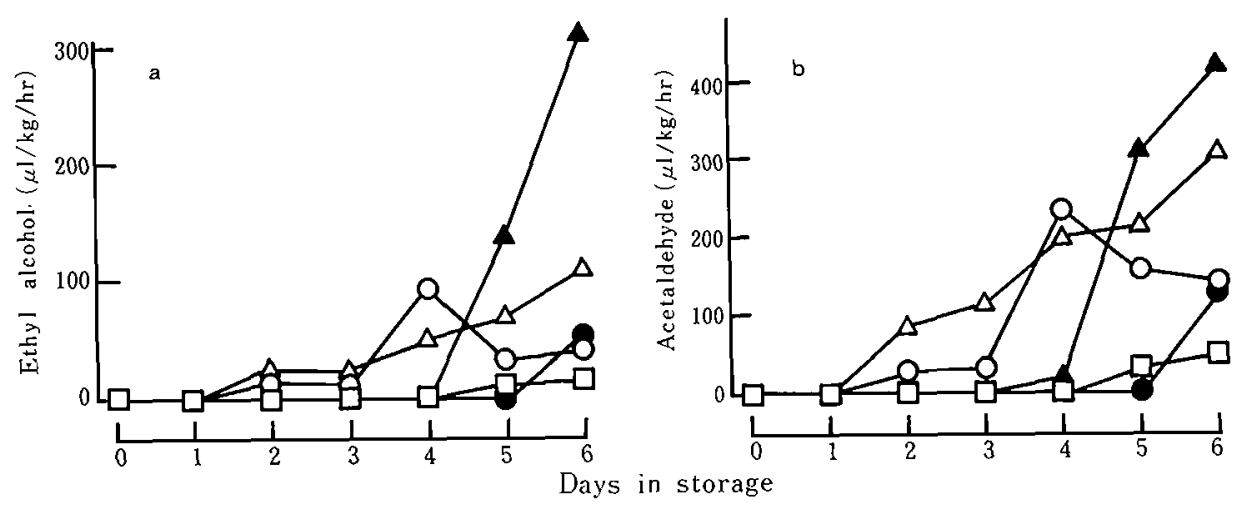

Fig. 6. Effect of sealing in polyethylene bags with or without an ethylene absorbent and/or a carbon clioxide absorbent on ethyl alcohol (a) and acetaldehyde (b) production of 'Gojiro' mume fruits during storage at $23^{\circ} \pm 2^{\circ} \mathrm{C}$. $\square$; perforated, $\mathrm{O}$; sealed, $\bullet$; sealed with $\mathrm{C}_{2} \mathrm{H}_{4}$ absorbent, $\Delta$; seald with $\mathrm{CO}_{2}$ absorbent, $\boldsymbol{\Delta}$; sealed with $\mathrm{C}_{2} \mathrm{H}_{4}$ and $\mathrm{CO}_{2}$ absorbents.

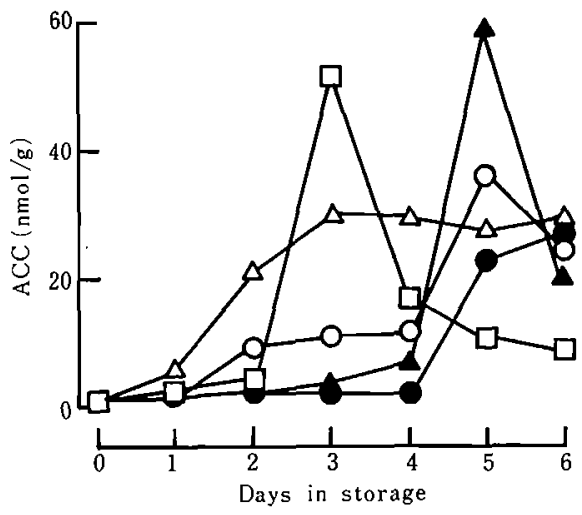

Fig. 7. Effect of sealing in polyethylene bags with or without an ethylene absorbent and/or a carbon dioxide absorbent on 1-aminocyclopropane-1-carboxylic acid (ACC) content of 'Gojiro' mume fruits during storage at $23^{\circ} \pm 2^{\circ} \mathrm{C}$. $\square$; perforated, $O$; sealed, $\bullet$; sealed with $\mathrm{C}_{2} \mathrm{H}_{4}$ absorbent, $\triangle$; seald with $\mathrm{CO}_{2}$ absorbent, $\Delta$; sealed with $\mathrm{C}_{2} \mathrm{H}_{4}$ and $\mathrm{CO}_{2}$ absorbents.

\section{5. 果実のACC 含量およびEFE 活性の変化}

前述のように処理区の間でエチレン生成量は非常に 相違したので，エチレン生成系の活性変化を調べる目 的で，果実の ACC 含量および EFE 活性を测定した。 まず ACC 含量の変化をみると(第 7 図)，有孔区では眝 藏 3 日に果実のACC 含品が急增し，ピークを示し，そ の後減少した，宸酸がス吸収郕封入区では眝藏 2 日か ら6日にかけてかなり高い值で推移しピークを示さず， エチレン除去剈を封入した 2 処理区では貯藏 4 日まで ACC 含㽞の增加が認められなかったが5 日から增加し

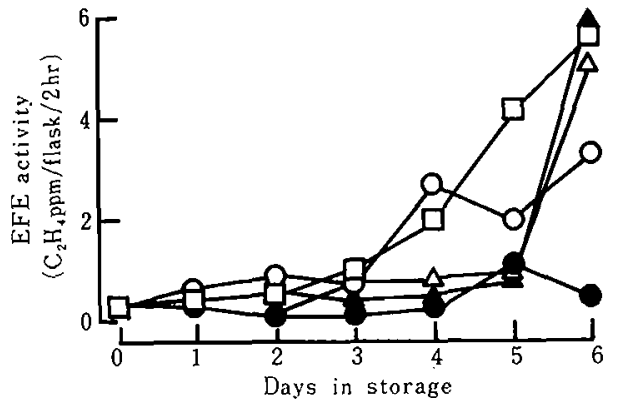

Fig. 8. Effect of sealing in polyethylene bags with or without an ethylene absorbent and/or a carbon dioxide absorbent on ethylene forming emzyme (EFE) activity of 'Gojiro' mume fruits during storage at $23^{\circ} \pm 2^{\circ} \mathrm{C}$. $\square$; perforated, $\mathrm{O}$; sealed, $\bullet$; sealed with $\mathrm{C}_{2} \mathrm{H}_{4}$ absorbent, $\triangle$; seald with $\mathrm{CO}_{2}$ absorbent, $\Delta$; sealed with $\mathrm{C}_{2} \mathrm{H}_{4}$ and $\mathrm{CO}_{2}$ absorbents.

た。この際炭酸がス吸収剂+エチレン除去剂封入区で は眝藏 5 日に非常に高いレベルに達した。密封区では 貯藏 4 日まで徐々に増加し，その後かなり高い值を示 した.

EFE 活性については第 8 困のように，有孔区におい て貯藏 2 日から增大して 6 日に最大值を示し，密封区 では貯藏 2 日から，炭酸がス吸収戍封入区では 3 日か ら EFE 活性の增大がみられ，いずれも 6 日に最大值を 示した。エチレン除去剤のみ䞑入した区では眝蔵 4 日 まで EFE 活性の増大が認められなかったが，その後少 し増大した。炭酸がス吸収肪十エチレン除去郕封入区 では5 日から增大し，6日に非常に高い値を示した。 


\section{考察}

青ウメは収穕後の追熟過程において，クライマクテ リック型の呼吸変化を示し(2)，エチレン生成量がきわ めて多いため，収稪後の青ウメの焦度保持は非常に困 難である．青果物のプラスチックフィルム包装によっ てもたらされる高炭酸がス，低酸素のガス珸境は果実 の呼吸代謝，エチレン生成係に影篦し，果実の追熟を 抑制するが，その変化の程度によっては果実に致命的 な生理障輩をもたらす $(1,4,10)$.

本実驗では青ウメを $0.02 \mathrm{~mm}$ ポリエチレンフィルム で密封包装すると相当の高炭酸ガスと低酸素浱度のガ ス環境が常温貯截 1 日以内で形成され，これによって 果実の追望が抑制されること，また，貯蔵開始から包 装内のエチレンを除去すれば，緑色の保持期間がさら に延長され，果実の硬度も保持された。しかし，高炭 酸がスと低酸菜㵊度の環境は果奏の星常代謝を引き起 こし，果箺によるアセトアルデヒドとエチルアルコー ルの生成,ならびに包装内蓄愤を促進した。このよう な条件下にある処理区の果実では果実内部に生理障害 が発生した。一为，貯蔵開始から包装内のエチレンを 除去すると，包装内の酸素㶆度の減少と炭酸がス激度 の增加をある程度怪娍し，アセトアルデヒドやエチル アルコールの生成と包装内覴䅡が少なく，果実内部の 生理乹害も生じなかった，包装内に炭酸がス吸収剤を 封入し，炭酸がス漃度を低くすることを試みたが，工 チレン除去刜を封入子る，しないにかかわらず，罳常 代謝や生理障害の発生が起こりやすく，貯蔵上逆効果 になった.このことは適度の炭酸がス湠度が生理活性 の抑制に効果的に作用していることを示しており，本

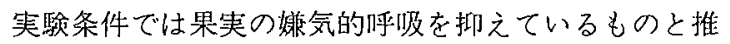
察される。

密封包装すれば, ACC 含最および EFE 活性の増加, エチレン生成最の增加が抑えられ，さらに貯蔵關始時 から包装内のエチレンを除去すると上記の効果が一層 顕著になった，一方，炭酸がス吸収剂による创装内の 炭酸ガス湍度の低下は，単に密封したものよりエチレ ン生成系の活性を促進する結果上なった，包装内に蓄 積した炭酸ガスによるエチレン生成系の抑制効果は炭 酸ガス吸収偊の封入によって炭酸がス漫度を減少させ るとかなり失われることが楒められた。以上のように 青ウメの包装盯藏においてフィルム包装とエチレン除 去剂を併用すれば，青ウメ収秘時の相当高い常温下で も一定期間の品質保持に有効なことが明らかになった。 しかし，本実験ではその效果の一部は一定範囲の低酸
素浼度と高岸酸ガス湍度の組み合わせの環境条件下で 現れるもので，その組み合わせが変わり，低酸素でも 炭酸がス浓度が低い場合にはエチレンを除去してもそ の效果が低下することが示された。

筬島ら(10)はメーカー, 製造方法, フィルム厚, 加 工法の異なるポリエチレン袋を用いて，エチレン・ア セトアルデヒド除去剤と併用して，青ウメの販蔵奏験 を行い，各フィルムの特性によって袋内炭酸がス濒度 差は生じたが，生理障害は炭酸がス激度約 $20 \%$ ，アセ トアルデヒド胀度 $2 \mathrm{ppm}$ 以上になると急增したと報告 した.また，宮琦(7)は青ウメ ‘白加賀”と ‘玉英”を用い， 常温 $\left(22^{\circ} \mathrm{C}\right)$ 貯葴の場合ではポリエチレンフィルム(厚さ $0.02 \mathrm{~mm})$ 包装された青ウメは舆包装より2 日程度, 工 チレン除去郕を併用すればさらに 2 日程度僬度保持期 間を延長することができたが，袋内酸菜螕度が $0.5 \%$ 以下になると果実に代謝異常やてれに伴う障害を発生 させることを報告した，本勧験では包装による青ウメ の维度保持は果奏のエチレン生成能が非常に低いレベ ルに維持されるためであること，またそれは包装内酸 素浱度約 $6 \%$ ，炭酸がス浓度約 $5 \%$ の条件でもたらさ れることが示され，低酸素のみでなく，炭酸がスの生 理活性抑制作用も重要であることを指摘した。

\section{摘 要}

青ウメ果実をポリエチレン袋に密封し常温 $\left(23^{\circ} \pm 2{ }^{\circ} \mathrm{C}\right)$ 貯藏して、エチレンおよび炭酸がス除去が果実の品質, 呼吸蛙，エチレン生成系，アセトアルデヒドおよびエ チルアルコール生成に及ばす影留について調べた.

1. 青ウメ果実の黄化拉よび果肉の軟化による品質 低下は，低密度ポリエチレンフィルム(厚さ $0.02 \mathrm{~mm}$ ) 密封刨装とエチレン除去戍封入との㴊用によって顕著 に抑制された。この抑制効果は，炭酸がス吸収剂封入 によって，包装内炭酸がス涔度を低下させると小さく なった。

2.エチレン除去削の掛入によって，包装内のエチ レンはほとんど除去され，また，密封包装のみのもの

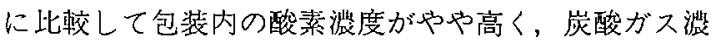
度がやや低くなった，単に密封したものおよび炭酸が ス吸収剂を封入したものでは，袋内にアセトアルデヒ ドおよびエチルアルコールが著しく漳積し，生理障㕩 による内部褐変が発生した。エチレン除去戍封入はこ

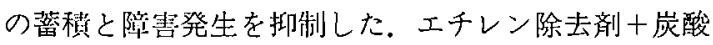
ガス吸収剤封入区ではアセトアルデヒドとエチルアル コールが涪䅡し，障害が発生した。

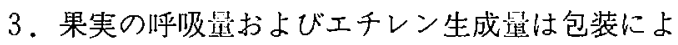


ク低下し，エチレン除去剤封入によりさらに低下した が，炭酸ガス吸收郕のみを封入すると単なる密封より 高くなった，エチレン除去郕と炭酸ガス吸収刜を同時 に封入すると一定期間内果実の呼吸とエチレン生成が 抑えられたものの，単にエチレン除去剤を使用した場 合よりその抑制効果が低かった。果肉中の ACC 含量は 果実のエチレン生成最の上昇に対応して同時期に堌加 する傾向を示した，EFE 活性は有孔区と密封区では早 く增大したのに对してエチレン除去剤封入区では盯藏 中低く抑之られた。炭酸がス吸収剤封入区，エチレン 除去剂十炭酸がス吸収剂封入区では EFE 活性は一定期 間低いレベルであったが，後期に急激な活性增大を引 き起こした。

謝辟 実臥材料を提供してくださった和歌山県 果樹試歌場紀北分場の北野欣信氏(現在，和歌山県果 樹囷芸試駼場本場)ならびに各位に，厚く御礼申し上げ ます。

\section{引用文献}

1. 兵藤 宏. 1978. 果実の成整(追䰻)とエチレン。 化学と生物 $16: 217-227$.

2. 稲策昭次・中村怜之輔。1981. ウメ果実の樹上及 び収榣後の成熟. 國学䧱. 49:601-607.
3. 北川愽镦. 1968, 青果物の包装に関卞る研究.

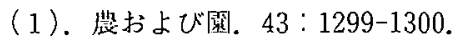

4. Lister, P. D., H. J. Lightfoot and K. B. Mcrae. 1983. Production and regeneration of principal volatiles in apples stored in modefied atmospheres and air. J. Food Sci. 48: 400-402.

5. Liu, F. W. 1970. Storage of bananas in polyethylene bags with an ethylene absorbent. HortScience $5: 25-27$.

6. Lizada, C. C. and S. F. Yang. 1979. A simple and sensitive assay for 1-aminocyclopropane-1-carboxylic acid. Anal. Biochem. 100:140-145.

7. 宮崎丈史. 1983. 青ウメの㸷度保持に及ぼす包装

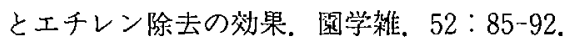

8. 宮崎丈史. 1985. 焦度保持剂. p. 106-109. 莀産 物流通技術年竍 (85 年版). 憵雇物流通技術研究 会䋧．淑流通システム研究センター，東京。

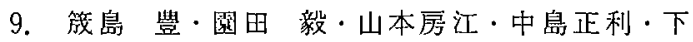
田满哉・松本 清。1983。エチレン吸収绪の開発 とその利用に関する研究。茈化誌。 57 ： 1127-1133.

10. 䈔島 豊・和田浩二・伊東裕子。1987。ウメ及び カボスの品質保持に及は付エチレン・アセトアルデ ヒド除去剤とフィルム密封包装の効果. 園学雑. $52: 524-530$

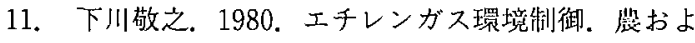
び圆. 55：1289-1293. 